\title{
An Ecocritical Reading of D. H. Lawrence's Women in Love
}

\author{
Dr.S.Janaki \&Dr.S.Sumathi \\ Assistant Professors, $P G \&$ Research Department of EnglishVellalar College for Women (Autonomous), Erode
}

\begin{abstract}
Literature is basically defined as that medium which serves to mirror life in all its facets and of recent times it concerns itself with the portrayal of the relationship between the human world and its physical environment, along with the constantly changing face of human connectivity with the natural world. Ecocriticism takes an earth-centered approach to literary studies. A man's inner being and the outer world have mutual correspondence and interdependence paving way to lead a wholesome life. The culture of living in tune with nature for a blissful life has been portrayed by many writers. In olden days man had been a part of nature but in the modern period he turns to be the exploiter of nature. Man must realize the intrinsic value of nature as well as the inseparable relation between mankind and the natural world. This paper attempts to explore D.H.Lawrence's Women in Love to bring out how his characters establish harmony and delicate balance with Nature. An ecocritical study of this novel brings out how his characters' emotional bonding with Nature is capable of tempering the mind and filling it with simple love, both for human and nonhuman beings. Lawrence neither idealises nor intellectualises Nature but presents it in a simple, direct and catchy way depicting their close association with the flourishing nature. Birkin and Ursula assimilate the pulse of nature which saturates their life with the highest gratification and riches. Their life correlated with the organic earth provides them surplus happiness and contentment.
\end{abstract}

Keywords: Ecocriticism, Nature, D.H.Lawrence, Women in Love

AN ECOCRITICAL READING OF D. H. LAWRENCE'S WOMEN IN LOVE

Literature is basically defined as that medium which serves to mirror life in all its facets and of recent times it concerns itself with the portrayal of the relationship between the human world and its physical environment, along with the constantly changing face of human connectivity with the natural world. Ecocriticism takes an earth-centered approach to literary studies. A man's inner being and the outer world have mutual correspondence and interdependence paving way to lead a wholesome life. The culture of living in tune with nature for a blissful life has been portrayed by many writers. In olden days man had been a part of nature but in the modern period he turns to be the exploiter of nature. Man must realize the intrinsic value of nature as well as the inseparable relation between mankind and the natural world. This paper attempts to explore D.H.Lawrence's Women in Love to bring out how his characters establish harmony and delicate balance with Nature. An ecocritical study of this novel brings out how his characters' emotional bonding with Nature is capable of tempering the mind and filling it with simple love, both for human and nonhuman beings.

Lawrence's The Rainbow and Women in Love reflect the current tendency in contemporary life and his nostalgia for the more organic life of England in the past. He endeavours to effectuate a bridge between the life of nature and the life of society, between natural permanence and human temporality. To him, modern culture, modern education and modern civilisation appear dead and mechanical. Lawrence has used Nature exquisitely in his novels. Most of his works exude his love for Nature and aversion for modernity. He tries to create a new cosmology far away from the chaos and confusion of modern world. This paper analyses ecocritically the life of two characters, Birkin and Ursula, in Women in Love, and an attempt is made to fit their life within an ecological framework. Ecological criticism envelops not only ecological concerns but also establishing a meaningful link with the organic Nature.

Women in Love is interpreted as a novel of relationships between man and woman, man and nature, and mind and body to explore the mystery of life. It is sequel to The Rainbow and recounts the life of four people who struggle to maintain their identities within romantic relationships. The characters' utmost concern is to assert his or her self, or personality. The characters undergo an epiphanic realisation of their stance; a transformation of mind and a change in their outlook towards life take place. Each character struggles to overcome their inner trepidations and tries to reach a saturating point in life. The experiences of love, desire, pain and frustration divulge the varied shades of life making them aware of the real side of existence. Each character in one way or other gets related to Nature which influences their mind, spirit and life. The contrast in the life of the two pairs, Birkin and Ursula, and Gerald and Gudrun, teaches a valuable lesson. The first pair is an exemplar 
for leading a cushy and wholesome life intertwined with Nature, and the latter's degenerated life forms a prototype of modernized lifestyle giving focus to money, power and fame moving away from simple natural life.

The inexperienced teenager, Ursula in The Rainbow has groomed into a modern woman. Rupert Birkin, a self-portrayal of Lawrence, feels that humanity is the root cause for the cycles of creation and decay in the universe. He is like a mouthpiece of Lawrence's philosophical attitude towards life and society. Birkin's visit to the school paves way for them to apprehend their mutual inclination. The atmosphere reflects the gentle blossoming of love between them. Birkin and Ursula's meeting takes place in a perfect ambience of sunshine and warmth. Lawrence has associated them with bright, vibrant and beaming nature indicating their enlivening futurity. Birkin's face “. . . in the shaft of ruddy, copper-coloured light near her, . . . gleaming like fire” (25) glows with tenderness at the sight of Ursula. The botany class in progression with ruddy flowers and leaves provides an apt setting for both to comprehend their unarticulated feelings nurtured towards each other. "There was a living, tender beauty, like a tender light of dawn shining from her face. He looked at her with a new pleasure, feeling gay in his heart, irresponsible" (25). Even their conversation revolves around the flowers and seeds which indicates a bourgeoning sunny future.

Birkin has no fixed abode and travels a great deal. He relates everything to the outer world which manifests his growing concern for society. He is very much against the modernised life condition that debases the worthy resources of the earth. His love for a life mingled with nature stands as a testimony for his great expectation towards the possibility of making the earth a befitting place to lead a salubrious life unmarred by mechanisation. He is highly worried of the depletion of healthy natural life conditions of the people. He expresses his great concern about the possibility of deplorable life in future. He is pained to witness the damages and ruin in the societal and natural setting due to the earthly desires. He feels that the machine civilisation robs the fecundity of mind and soil. He is of strong opinion that material pursuits may enhance the life style of the people but will spoil the kernel of existence. He advocates for a life connected with the bounty of nature resenting the crude artificialities of modern life. Every way," said Birkin. "We are such dreary liars. Our one idea is to lie to ourselves. We have an ideal of a perfect world, clean and straight and sufficient. So we cover the earth with foulness; life is a blotch of labour, like insects scurrying in filth, so that your collier can have a pinaforte in his parlour, and you can have a butler and a motor-car in your up-to-date house, and as a nation we can sport the Ritz, or the Empire, Gaby Deslys and the Sunday newspapers. It is very dreary" . . . "And what's your work? Getting so many thousands of tons of coal out of the earth every day. And when we've got all the coal we want, and all the plush furniture, and pianofortes, and the rabbits are all stewed and eaten, and we're all warm and our bellies are filled and we're listening to the young lady performing on the pianoforte-what then? What then, when you've made a real fair start with your material things?" (41-42) Birkin does not take any medical aid for the injuries caused by Hermione Roddice. He moves on to a wild valley-side although there is a danger that he might become unconscious at any moment. He experiences an epiphanic moment in being one with nature. His mode of treatment for his injury is to strip himself naked and roll in the grass in order to be closest to nature. In Robert Frost's "Stopping by Woods on a Snowy Evening", the narrator is transported to an ecstatic world by the beauty of the snow-filled woods. His mind gets so engrossed in the scenic beauty that he forgets for a while his duties and obligations. Nature relieves his worries for time being and provides consolation to his disturbed mind. In the same way, Birkin's mind gets entwined in intimate, mystic contact with the world of nature. He wishes to become a part of divinely sanctioned order of nature. He identifies himself with green and pleasant land. The conception related to nature's greatness is pointed out in the essay "The Drunken Boat" by Frye in The Stubborn Structure:Nature to Wordsworth is a mother-goddess who teaches the soul serenity and joy, and never betrays the heart that loves her; to the Marquis de Sade nature is the source of all the perverse pleasures that an earlier age had classified as 'unnatural'. For Wordsworth the reality of Nature is manifested by its reflection of moral values; for de Sade the reality is concealed by that reflection . . . The corn-goddess in Keats' To Autumn, the parallel figure identified with Ruth in the Ode to a Nightingale, the still unravished bride of the Grecian urn, Psyche, even the veiled Melancholy, are all emblems of a revealed Nature. (213-14) To Birkin, Nature is the true and appropriate home of man which injects the animating essence of life into him. His conviction of Nature's greatness gets stronger as he senses a high degree of satisfaction enveloping his mind. A fervent and genuine love towards Nature starts to mature in Birkin. The nature kindles, refines and cheers his bruished body and spirit. He wants nothing but to roll in the lap of Nature to enliven his tormented soul. His mind falls into philosophical musings related to the sickening life of man proceeding after hopeless material and emotional pursuits. He feels that he has found a new world of ecstasy which incorporates in it the elements of bliss and stillness. It transports him to a happy domain far away from the common mechanical life. He realises his inner aspirations and finds the proper environment where he really longs to attach himself. A meaningful insight on life flashes through him and gives him ample strength to overlook his grief. Nature gives him a new knowledge revealing the enchanting facade of life. He shuns the extraordinary sanity of the external world. He went through the long grass to a clump of young fir-trees, . . . soft sharp boughs beat upon him, . . . to lie down and roll in the sticky, cool young hyacinths, to lie on one's belly and cover one's back with handfuls of 
fine wet grass, soft as a breath, soft and more delicate and more beautiful than the touch of any woman; and then to sting one's thigh against the living dark bristles of the fir-boughs; . . this was good, this was all very good, very satisfying. Nothing else would do, nothing else would satisfy, except this coolness and subtlety of vegetation travelling into one's blood. How fortunate he was, that there was this lovely, subtle, responsive vegetation, waiting for him, as he waited for it; how fulfilled he was, how happy! . . . The leaves and the primroses and the trees, they were really lovely and cool and desirable, they really came into the blood and were added on to him. He was enrichened now immeasurably, and so glad. (86-87)He wants to touch all the bushes and flowers to saturate him with their contact. The touch of the flowers on his naked body is fine, cool and delicate. It soothes his tortured mind and body. This is the touch of Prakriti, a manifestation of feminine principle which eases and consoles the wounded soul. Beulah for Blake is the earthly paradise, the state of innocence, the peaceful kingdom and married land of Isaiah. It is a world of imagination where there is comfort and entertainment, where one need not struggle out of the tyranny and anarchy of modern life. Such a feeling of innocent happiness and consolation Birkin enjoys in the beautiful valley. The beauty of Nature offers him solace and comfort for which his mind and body yearn to relish. The verdant atmosphere restores his vitality and reanimates his energy. It gives him the stamina that uplifts his enervated spirit. It confers on him a strange happiness and fulfilment. He supposes himself to be fortunate in the midst of lovely and sensitive vegetation. He is enriched by his primitive kinship with the enchanting nature. "Here was his world, he wanted nobody and nothing but the lovely, subtle, responsive vegetation, and himself, his own living self" (87). He does not mind Hermione's attack very much and characterises it as one of her spontaneous actions. After the great deluge, Noah with his companions travels by a boat across the vast stretch of water where there are no human beings, with a hope for a bright future. Here, Birkin and Ursula float across the pond wishing for a world rich with flora and fauna without the interference of human beings. There is perfect stillness and the area is overgrown with bushes and trees, a perfect ambience for the two souls to recognise each other's deep attraction and liking. Their love towards Nature's bounty comes out as they scout around the wild growth. They start to speak their mind out, unconsciously exploring the other person's aspirations. Birkin's close association with Nature gets revealed in his comparison of humanity to a tree and human life to a healthy apple but points out that "their insides are full of bitter, corrupt ash" (102). Birkin is disappointed with humanity and is pessimistic about its future. He is happy to imagine a world in which mankind is to be completely wiped out and exist with just uninterrupted grass and animals. He sticks to his point that mankind is a mistake of nature. Birkin's deep longing for the prevalence of unblemished Nature makes him imagine a world profuse with animal and plant life. Even Ursula tries to visualize a world without man and feels that the human-less earth would be a clean and lovely inhabitation. Do you think that creation depends on man! It merely doesn't. There are the trees and the grass and birds. I much prefer to think of the lark rising up in the morning upon a human-less world. Man is a mistake, he must go. There is the grass, and hares and adders, and the unseen hosts, actual angels that go about freely when a dirty humanity doesn't interrupt them-and good pure-tissued demons: very nice. (104)They distract themselves by throwing daisies into the water. The brilliant little discs of daisies evoke a strange sensation in Ursula which is beyond her understanding. The daisies were scattered broadcast on the pond, tiny radiant things, like an exaltation, points of exaltation here and there. Why did they move her so strongly and mystically? ... Some of the daisies came slowly towards her, hesitating, making a shy bright little cotillion on the dark clear water. Their gay bright candour moved her so much as they came near, that she was almost in tears. (106)She cannot decipher the reason for her emotional exaltation. The little flowers kindle her spirit to an extent of putting her in tears. She is infused with mysterious feeling of exhilaration and gives out an ecstatic sigh of happiness. From the beginning of their relationship Birkin and Ursula are linked to the resplendent, beaming side of nature. Indirectly the beautiful nature also paves way for strengthening their mutual understanding. The flourishing greenery and radiant flowers soothe and check their temper, bringing them closer spiritually and physically. Ursula identifies and binds herself with the moon, the womanly "lunar" side of nature. As the moon's reflection splits, Ursula suffers: "Ursula was dazed, her mind was all gone. She felt she had fallen to the ground and was spilled out, like water on the earth" (206). Lawrence's mastery at the art of description and love of natural beauty becomes known in his beautiful and vivid picturisation of how the fragments of light come together to form the image of moon. As hope of their union appears to wax, the moon appears white, bright and victorious like Ursula. The scattered flakes of light draw together like rose petals, a symbol of complete love, when man and woman enter into a pure and perfect life of wholeness. Though even now she was aware, unseeing, that in the darkness was a little tumult of ebbing flakes of light, a cluster dancing secretly in a round, twining and coming steadily together. They were gathering a heart again, they were coming once more into being. Gradually the fragments caught together reunited, heaving, rocking, dancing, falling back as in panic, but working their way home again persistently, making semblance of fleeing away when they had advanced, but always flickering bearer, a little closer to the mark, the cluster growing mysteriously larger and brighter, as gleam after gleam fell in with the whole, until a ragged rose, a distorted, frayed moon was shaking upon the waters again, reasserted, renewed, trying to recover from its convulsion, to get over the disfigurement and the agitation, to be whole and composed, at peace. (206) 
After their exchange of tender emotions in the quaint atmosphere of a local inn, they embark on a refreshing drive through the dark wood of Sherwood Forest where they have a magnificent union of body and soul. The calm locale forms an apt background for their happy union. The moment of quietude prevailing in the forest entrances them. The undisturbed natural setting serves to be the perfect milieu for the masculine and feminine revelations. They revel in the secret refreshing experience in the dark night. Lawrence's lovers quite often make love under open sky far from the ambiguities of the civilised city life. In The Rainbow, the exchange of love between Anna and Will in the moonlit night where the whole milieu is steeped into the rustic background is soothing and quieting. The lovability factor reaches the highest quotient. The viability of the moon encompassing spectacular changes makes it an endearing figure of representation. The method of projecting light makes the moon a symbol of subtlety. Gerald and Gudrun join them at Innsbruck, a wonderful place deep in snow. They enjoy a lot but after a few days Ursula starts to feel repugnant towards the white, dull, snow covered mountains. She feels suffocated as if the cold strangles her soul. She wants to melt into fresh and active life with full of energy and enthusiasm. The pure hard whiteness of snow pierces her soul causing intolerable pain. It blocks her senses and feelings. A sudden urge to leave the place oppresses her. Ursula's love and link with flowery nature propel her to leave the barren chilly mountainous region. She yearns for a plenteous world vibrating with the profusion of bright natural harmonies. The very thought of greeny atmosphere instigates her to leave the snowcapped mountains. Her whole self rejoices at the visualisation of the blue sky, the smell of the soil and the brilliant sunshine. Ursula went out alone into the world of pure, new snow. But the dazzling whiteness seemed to beat upon her till it hurt her, she felt the cold was slowly strangling her soul. Her head felt dazed and numb. Suddenly she wanted to go away. It occurred to her, like a miracle, that she might go away into another world. She had felt so doomed up here in the eternal snow, as if there were no beyond. . . . She wanted at this instant to have done with the snow-world, the terrible, static ice-built mountain tops. She wanted to see the dark earth, to smell its earthy fecundity, to see the patient wintry vegetation, to feel the sunshine touch a response in the buds. (366) Ursula regains tranquility by thinking of Italy's fecund earth. The outer world that is related to them symbolises life, vitality, hopefulness and prosperity. They usually go to the places full of flowers, trees and grass which suggest refreshing mind and approach to life. She runs to the house "full of hope" to tell Birkin that they must leave the doomed land of "eternal snow". Next day Ursula and Birkin leave for Verona, an exuberant place of life and action. They have worked painfully towards fulfilment in life and yearn to continue it. With the full acceptance of the body and of desire, they have achieved liberty and enter into a new commitment to each other. Their intimacy has a quality of comforting and soothing warmth and a hopeful promise. Modern living is a mere automation, if a man lets his will power, personality and ideals interfere with his relation to other men, women and the universe, then the relationship will be sterile lacking in emotional depth and sincerity. The industrial system decimates the valuation of human worth. The desire for creation and productive happiness is replaced by the impulse for progressive knowledge. There should be a revolution within each individual to liberate the mind from its materialistic chains. In Women in Love, there is a growth of mind and a sense of maturity in Ursula and Birkin. They start to experience a new way of life by unfolding their inner self for a better life and understanding. They try to resolve oneness with the full acceptance of the body and soul and achieve a new commitment and dualism. Their individuality, positive and natural human relationship take them in the path to form a part of the living continuum of the universe. Everything becomes possible for them only because of their close connectivity with Nature. It refreshes and rejuvenates their life. Lawrence neither idealises nor intellectualises Nature but presents it in a simple, direct and catchy way depicting their close association with the flourishing nature. Birkin and Ursula assimilate the pulse of nature which saturates their life with the highest gratification and riches. Their life correlated with the organic earth provides them surplus happiness and contentment. There exists an atmosphere of energetic involvement in enriching the fecundity of the soil and thereby they lead a productive life. Nature kindles their active spirit from its dormant state filling up their life with great enthusiasm. The lifeenergy gushing out of the earth enlivens their distraught mind. The vibrant nature electrifies their whole being making them an active participant in the worldly affairs. The significant moments in their lives have a strong interrelation with the body of the soil. Nature includes within it the promising quality of bestowing peace and equipping the mind and body with power to challenge the grim realities. Both Ursula and Birkin grow to maturity with the dynamism of their relationship. Though they are repelled by the mechanised wilderness of the modern world, they move towards distinctiveness amidst the disintegration and dissolution by their positive relationship and closeness with Nature which soothes and refreshes their mental and physical agony. A meaningful relation, a healthy pact of mind and a perfect warm life is sure to flourish if our life is intermixed with fecund earth.

Works Cited:

1. Frye, Northrop. The Drunken Boat: The Revolutionary Element in Romanticism. The Stubborn Structure: Essays on

Criticism and Society. London and New York: Methuen, 200-17. 1970. Print.

2. Lawrence, D.H. Women in Love. New York: Dover Publications, INC. 2002. Print. 